\title{
The electrical demand by transport on the grid after oil depletion
}

\author{
J.J. Wolmarans, J.A. Ferreira \\ Electrical Power Processing \\ Faculty Electrical Engineering, Mathematics and Computer Science \\ Delft University of Technology \\ Delft, the Netherlands \\ $+31152781898$ \\ J.J.Wolmarans@TUDelft.nl, J.A.Ferreira@TUDelft.nl
}

\begin{abstract}
At the hand of a case study alternathe energy sources, methods of transportation and their effect on the electric ing grid once fossif fuels have been depleted is discussed. Three methods of sustainable transport are presented. The energy requirement for each is calculated as nell as the requirements from the electric ing grid for traveling a $200 \mathrm{~km}$ route. All three proposed methods are compared to current methods of transport. Specifically, the Superbus, an all electric vehicte, has also been considered as an alternative to future transport. The results obtained indicates that the Superbus is the better option regarding energy requirement from the electricty grid, while at the same time traveling at high speeds to make point to point transportation fast.
\end{abstract}

Keywords: Superbus, mass transport, electricity gria, renenuble energy

\section{INTRODUCTION}

Abandoning the use of fossil fuels, whether by choice or by necessity raises the question of where new energy sources will be found. Currently, various alternative fuels exist, but their energy requirement from and impact on the electricity grid is unknown. Even though the combustion of fossil fuels does not require any energy from the electricity grid itself, the process of extraction and processing fossil fuels do require external energy, usually supplied by the electricity grid.

The electricity grid should be dimensioned to be able to cope with the demand for delivering fuels, whether it is extraction, processing or transportation. If oil reserves are depleted, the demand from the grid will most probably change and the impact of sourcing the required energy to fill the void is unknown.

Figure 1 shows electricity generation break-down by fuel type for 2004. This summates to a total of $17,450 \mathrm{TWh}$ of energy generated in the year 2004. Noticeable is that the largest percentage of electricity is generated from coal. Even at $6.7 \%$ share, energy generated from oil still equates to $1,167 \mathrm{TWh}$. Once oil reserves have been depleted, this energy will have to be sourced from somewhere else.

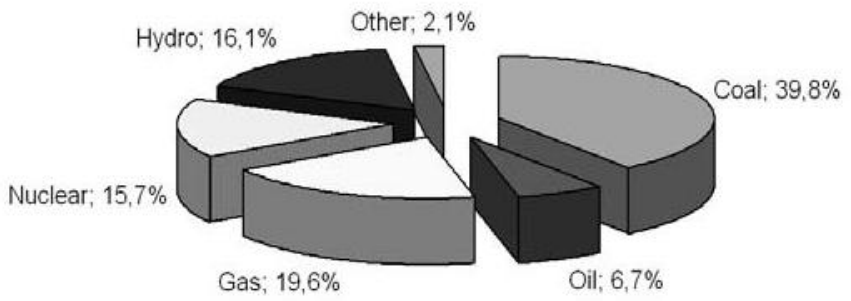

Figure 1 Electricity generation by fuel for 2004 [1]

Figure 2 shows the consumption of oil by sector. Considering the transport sector, it can be seen that this is the largest fraction consumed. This will leave a considerable deficit once oil resources are depleted, which will have to be compensated.

Moving away from fossil fuels is possible, by making use of bio-fuels like bio-ethanol or bio-diesel.

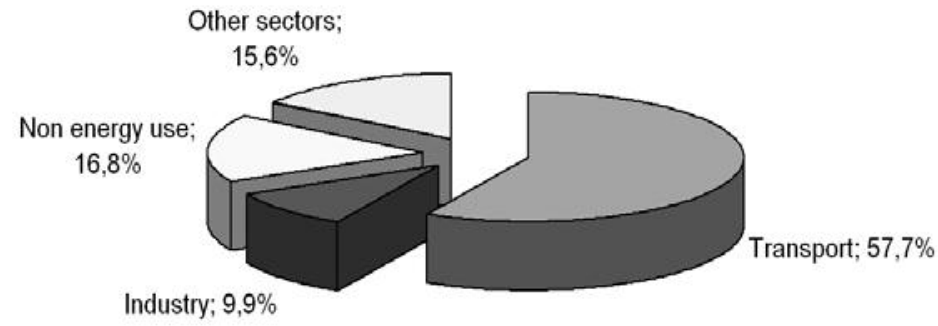

Figure 2: World final consumption by oil sector for 2004 
Another possibility is that this energy supply will come solely from the electricity grid. Using full electric vehicles will also help to move to a carbon neutral society by relying on sources with no emission. This depends however on whether the electricity grid is supplying sustainable energy or not. By utilizing only renewable sources like wind, hydroelectric, wave and solar power, sustainability is achieved. This will be discussed later in this paper.

Using electricity readily available from the grid is the first possibility, although figure 1 shows that the electricity generated is currently not $100 \%$ sourced from renewable sources.

The goal of this paper is thus to investigate current and future demand from the electricity grid depending on the type of fuel used in future transport and investigate plausible alternative technologies, assuming the use of fossil fuel is not possible. To investigate the possibility of future transport, the energy requirements for plausible methods of transportation need to be calculated.

\section{TRANSPORT SYSTEM}

In Europe, most inter-city routes are covered by trains powered by overhead electricity lines. Although inter-city trains are in widespread use today, they are not a good option for developing technologies. To be able to commission a new train line or service, new track needs to be laid and accompanying infrastructure like bridges, crossroads and stations needs to be built. It is therefore not a very flexible alternative to oil-free transport.

Three alternative methods of transport will be considered:

- Commuter bus

- Helicopter

- Superbus

To gauge the energy required to travel the suggested route, these vehicles will all be assumed to travel an equal distance. The energy required for these different methods to travel the same distance will be estimated and compared using fossil fuels as well as non fossil based fuels.

Vehicle parameters are shown in Table I.

Table I Vehicle parameter comparison

\begin{tabular}{|c|ccccc|}
\multicolumn{1}{|c}{} & Passengers & $\begin{array}{c}\text { Empty } \\
\text { Weight }(\mathbf{k g})\end{array}$ & $\begin{array}{c}\text { Engine } \\
\text { Power }(W)\end{array}$ & $\begin{array}{c}\text { kW/ } \\
\text { passenger }\end{array}$ & $\begin{array}{c}\text { kW/ } \\
\text { kg }\end{array}$ \\
\hline Commuter bus & 58 & 10.000 & 110.000 & 1,90 & 0,01 \\
Helicopter & 6 & 2.100 & 600.000 & 100,00 & 0,29 \\
Superbus & 25 & 6.800 & 500.000 & 20,00 & 0,07 \\
\hline
\end{tabular}

A proposed method of transportation will also want to be fast. For this reason the helicopter and Superbus have been chosen for this case study, to be able to calculate energy requirements for fast point to point transportation as well.

The amount of passengers that every vehicle can transport is not the same, so to make a meaningful comparison the amount of passengers will be normalized to the transportation of 1000 passengers in both directions, which might constitute the daily traffic for such a route. This figure might then be used to determine the installed capacity that would be required from the electricity grid.

\section{Commuter Bus and Helicopter}

These two vehicles were chosen for use in this comparison to represent current methods of transport. They are not necessarily both efficient and fast, but they are in widespread use and well known.

\section{Superbus}

One proposed solution for future point to point transport is the Superbus, currently under development (rendering shown in figure 3). The Superbus will be charged from the electricity grid and store its energy onboard using batteries. Key parameters are shown in Table II.

Table II Superbus key parameters

\begin{tabular}{|c|c|c|c|c|c|}
\hline Top speed & Power output & Range & Weight & Length & Height \\
\hline $250 \mathrm{~km} / \mathrm{h}$ & $500 \mathrm{~kW}$ & $200 \mathrm{~km}$ & $8500 \mathrm{~kg}$ & $10 \mathrm{~m}$ & $2,5 \mathrm{~m}$ \\
\hline
\end{tabular}

The development of the Superbus stems from the necessity for new methods of public transport and is also aimed to provide high speed sustainable transport. The Superbus will make use of existing bus stations and terminals and does therefore not require any disruptive construction in built up areas like city centers. The Superbus will be able to reach similar top-end speeds as high-speed trains in use today, but with a larger freedom to move on almost any particular route.

The proposed route for the Superbus is the $200 \mathrm{~km}$ distance between 2 cities, Amsterdam and Groningen in the Netherlands, although any similar route may apply.

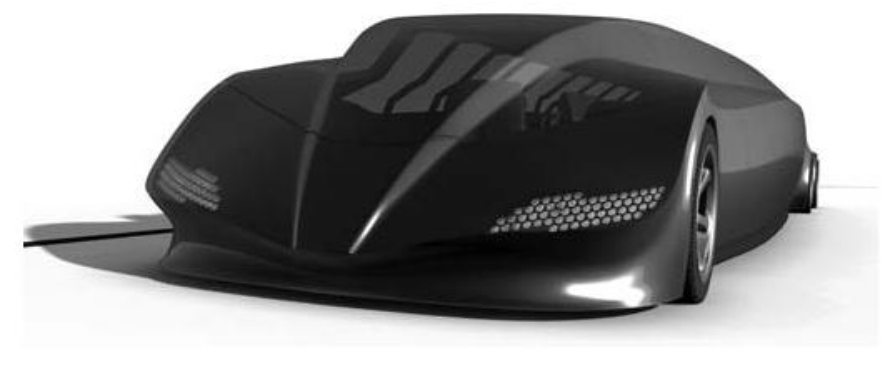

Figure 3: Frontal view of Superbus 


\section{ENERGY REQUIREMENT OF CURRENT TRANSPORTATION METHODS}

To be able to calculate the energy required to complete the specified distance an average speed will be assumed and some traveling time will result. This average speed will then be used to compare other methods of transportation discussed in this paper.

Two average speeds will be used to base calculations on, $120 \mathrm{~km} / \mathrm{h}$ and $240 \mathrm{~km} / \mathrm{h}$. Not all vehicles considered in this paper can travel at all speeds. Table III lists which vehicle can operate what speed. Table 4 gives an indication of the resulting traveling time for a $200 \mathrm{~km}$ distance.

Table III Possible vehicle speeds

\begin{tabular}{|c|cc|}
\hline Vehicle & \multicolumn{3}{c|}{ Traveling speed (km/h) } \\
& 120 & 240 \\
\hline Commuter Bus & $\mathrm{X}$ & $\mathrm{O}$ \\
Helicopter & $\mathrm{X}$ & $\mathrm{X}$ \\
Superbus & $\mathrm{X}$ & $\mathrm{X}$ \\
\hline
\end{tabular}

(X-possible, $\mathrm{O}-$ not possible)

Table IV Traveling speeds and times for $200 \mathrm{~km}$ journey

\begin{tabular}{|c|cccc|}
\hline Traveling speed $(\mathbf{k m} / \mathbf{h})$ & 60 & 120 & 180 & 240 \\
\cline { 2 - 5 } Traveling time (hours:minutes) & $3: 20$ & $1: 40$ & $1: 07$ & $0: 50$ \\
\hline
\end{tabular}

\section{A. Commuter bus}

A medium sized commuter bus is considered for this discussion. Such busses use mostly diesel engines with peak power output ranging from $90 \mathrm{~kW}$ to $140 \mathrm{~kW}$ [9] (see Table $1)$.

Table 4 indicates traveling at an average speed of $120 \mathrm{~km} / \mathrm{h}$ will complete the journey in 1 hour and 40 minutes. Energy consumed is calculated by using the specified fuel consumption rate and the specific energy density for diesel.

The power required for the commuter bus to travel at $120 \mathrm{~km} / \mathrm{h}$ can be calculated if some parameters are assumed. The sum of the aerodynamic drag, $\mathrm{F}_{\text {aero, }}$ and rolling resistance, $F_{\text {roll }}$ of the commuter bus are used to determine the total retarding force. Their direction is shown in figure 4.

The power required is calculated as follows:

$$
\mathrm{P}=1 / 2 \rho \mathrm{C}_{\mathrm{d}} \mathrm{Av} v^{3}+\mathrm{C}_{\mathrm{rr}} \mathrm{mv}^{2}
$$

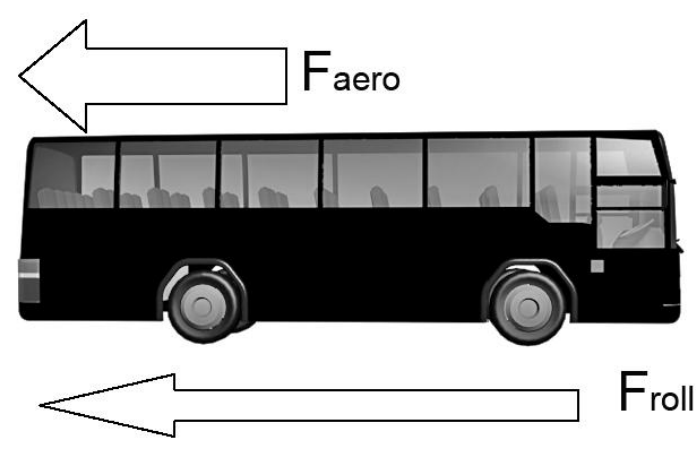

Figure 4: Retarding forces on commuter bus

The following assumptions are used:

- Air density: $\rho=1.293 \mathrm{~kg} / \mathrm{m}^{3}$

- Drag coefficient: $\mathrm{C}_{\mathrm{d}}=0.65$

- Rolling resistance coefficient: $\mathrm{C}_{\mathrm{rr}}=0.03$

- Frontal area: $\mathrm{A}=6.21 \mathrm{~m}^{2}$

- Air velocity: $\mathrm{v}=33.33 \mathrm{~m} / \mathrm{s}$

- Vehicle mass: $\mathrm{m}=10000 \mathrm{~kg}$

Calculating the power required using (1) yields almost $107 \mathrm{~kW}$. Rounding this up and assuming the engine produces an average power of $110 \mathrm{~kW}$ over the whole route, yields an energy requirement of $183 \mathrm{kWh}$.

Specific fuel consumption is obtained from the engine manufacturer datasheet [3], and the gravimetric amount of fuel required calculated. For a fuel flow rate of $215 \mathrm{~g} / \mathrm{kWh}$ the weight of the fuel consumed is $39.35 \mathrm{~kg}$. Table 5 lists the specific energy and fuel densities. Using a fuel density of $850 \mathrm{~g} / \mathrm{liter}$, this equates to about 46.3 liters of diesel. Using the specific energy of diesel from Table $V$, the energy consumed is calculated to be $1.8 \mathrm{GJ}$.

\begin{tabular}{|c|c|c|c|}
\multicolumn{4}{c|}{ Table $\vee$ Vehicle fuel types } \\
\hline Vehicle & Fuel type & Fuel density & Fuel energy \\
\hline Commuter bus & Diesel & $850 \mathrm{~g} / \mathrm{L}$ & $45,9 \mathrm{MJ} / \mathrm{kg}$ \\
Helicopter & Kerosene & $715 \mathrm{~g} / \mathrm{L}$ & $43,7 \mathrm{MJ} / \mathrm{kg}$ \\
\hline
\end{tabular}

\section{B. The helicopter}

A commercially available 6 seat helicopter is considered for comparison. The power plant is a $500 \mathrm{~kW}$ turbo shaft engine and the total weight of the helicopter is $2500 \mathrm{~kg}$ (including passengers). Speed will be matched to that of the commuter bus so that traveling time will be the same. 
Firstly, considering retarding forces acting on the helicopter, rolling resistance is absent and the only forces are air friction $\left(\mathrm{F}_{\text {aero }}\right)$ acting in the forward direction and gravitational force $\left(\mathrm{F}_{\mathrm{g}}\right)$, of which directions are shown in figure 5 .

Energy is required to propel the helicopter forward and overcome air resistance. Some energy is also required to overcome gravity, but this is stored energy and is reclaimed when the helicopter descends back to earth. Most energy is required to keep the helicopter in the air, however no work is being done if the helicopter is only hovering. This is also partially true when the helicopter is in constant altitude flight, as a component of the force is to simply keep the helicopter at a certain altitute.

Energy required to complete the journey will be derived from the fuel flow during flight. By determining how much fuel is consumed we can determine the energy required.

Manufacturers' datasheet [4] gives fuel flow at this speed to be between $90-105 \mathrm{~kg} / \mathrm{hr}$, depending on altitude and load. This equates to a total of 245 liters of fuel used. Using aviation fuel energy content of $43.71 \mathrm{MJ} / \mathrm{kg}$ [5] we calculate the energy consumed to be $7.6 \mathrm{GJ}$.

It is, however also possible to reach higher speeds with this type of vehicle. Increasing the traveling speed to an average of $240 \mathrm{~km} / \mathrm{h}$ also increases the fuel consumption rate to $160 \mathrm{~kg} /$ hour but traveling time is shortened to 50 minutes. The energy required then is $5.8 \mathrm{GJ}$.

We notice that even though the fuel consumption rate increased, the total amount of fuel and thus the amount of energy consumed actually decreased because of the shortened trip time. Table VI summarizes energy and fuel consumption for both types of vehicles.

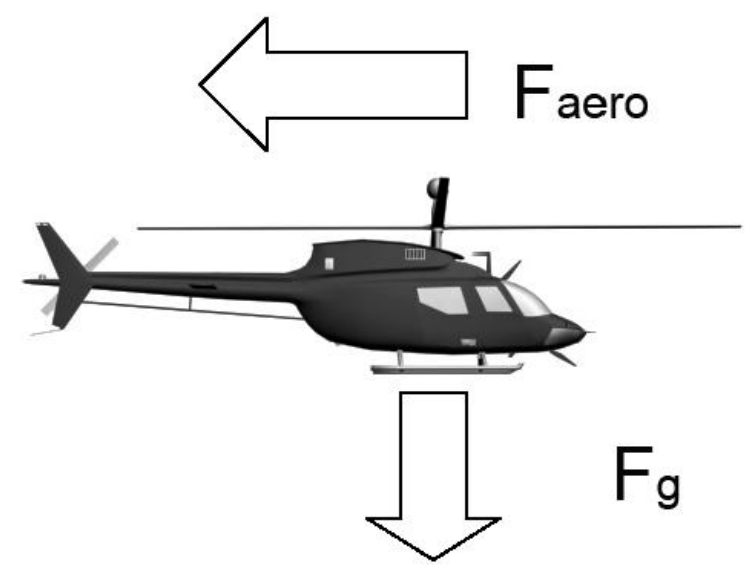

Figure 5: Retarding forces on helicopter
Table VI. Fuel and energy consum ption for commuter bus and helicopter over $200 \mathrm{~km}$

\begin{tabular}{|l|cc|cc|}
\hline \multicolumn{3}{|c|}{$\mathbf{1 2 0 k m / h}$} & \multicolumn{3}{c|}{ 40km/h } \\
Vehicle & Consumption & Energy & Consumption & Energy \\
\hline Commuter bus & 46.3 liters & $1,8 \mathrm{GJ}$ & N/A & N/A \\
Helicopter & 245 liters & $7,6 \mathrm{GJ}$ & 151 liters & $5,8 \mathrm{GJ}$ \\
\hline
\end{tabular}

\section{AFTER OIL DEPLETION}

Both examples discussed are highly reliant on fossil fuels, using diesel and kerosene (jet fuel) for commuter bus and helicopter, respectively. Considering running the bus on bio ethanol and the helicopter on hydrogen produced using renewable energy presents a solution to transportation after oil depletion.

Introducing the Superbus concept, charged from renewable electric energy sources like wind or solar power could also present a method of renewable transportation in the future.

\section{A. Commuter bus:}

Running the commuter bus on bio-ethanol has been proposed. Ethanol can be mass produced by fermentation of crops or feedstocks to yield either pure bio-ethanol or be blended with other fuels for use in conventional vehicles. Bio ethanol is seen as a renewable energy source, because it is based on a conversion process in which renewable feedstocks are converted into fuel.

The drawback of fuel derived from natural feedstocks is the reduced specific energy compared to fossil fuels [6]. The use of natural feedstocks also threatens human food supplies. The specific energy within the feedstock derived fuel is also highly dependent on the type of feedstock used. These feedstocks include (but are not limited to) switchgrass, sugarcane and corn.

Currently the use of material with high cellulose content is being tested by using the process of cellulolysis. Cellulosic ethanol is chemically identical to bio ethanol, but is produced from cellulose. This process involves the use of cellulytic bacteria, fungi or enzymes to break cellulose down into shorter cellodextrins. This increases the yield of feedstocks with higher cellulose content, which is not digestible by humans and thus also does not threaten food supplies.

The method of cellulolysis is currently not in commercial use yet. Still, both sugar and cellulose based ethanol will be discussed. 
Assuming the diesel engine of the commuter bus has an efficiency of $35 \%$ and an engine running on ethanol has an efficiency of $25 \%$, we can calculate the difference in energy required to continue running the bus. Running an engine on bio-ethanol also increases fuel consumption by $33 \%$ because of the reduced energy content associated with it. Appropriate adjustment of the engine can keep power output the same [6].

Table VI lists that the commuter bus running on diesel required $1.8 \mathrm{GJ}$ of energy, so conversion to bio-ethanol will increase the energy requirement to almost $3.4 \mathrm{GJ}$. According to [6][11], between $0.59 \mathrm{MJ}$ and $1.14 \mathrm{MJ}$ of energy is required to produce $1 \mathrm{MJ}$ of corn based bio-ethanol.

Discarding the largest and smallest values, an average of $0.72 \mathrm{MJ}$ is used for calculations. This translates to $2.45 \mathrm{GJ}$ of energy required to produce enough bio-ethanol to run the commuter bus for $200 \mathrm{~km}$. This translates into $680 \mathrm{kWh}$ of electrical energy required from the electrical grid.

Assuming such a commuter bus can accommodate 58 passengers per trip, this equates to $11.7 \mathrm{kWh}$ per passenger in one direction. To transport 1000 people the $200 \mathrm{~km}$ distance and back would therefore require $23.4 \mathrm{MWh}$. This gives an indication of the average power that could be required over a 24 hour period.

These calculations are based on the use of corn based ethanol and not cellulose derived ethanol. If it does indeed become commercially possible to produce bio ethanol from cellulose based feedstocks, not only will the yield be higher but the energy required to produce the fuel will be considerably lower.

To produce one megajoule of bio ethanol from cellulose based feedstocks requires only between $0.1 \mathrm{MJ}$ and $1.1 \mathrm{MJ}$ of energy, compared to $0.72 \mathrm{MJ}$ required for corn based feedstocks [6][11]. Again discarding the largest and smallest values, an average of $0.2 \mathrm{MJ}$ is used for calculations.

Cellulose based ethanol with an energy content of $3.4 \mathrm{GJ}$ will now require only $0.68 \mathrm{GJ}$ of energy and electrical energy from the grid now decreases to $188.9 \mathrm{kWh}$.

This energy requirement from the electricity grid is for an average of one day. Energy required during a 24 hour period is then calculated by normalizing the energy per vehicle to the energy per person. This is then used to calculate the energy per 1000 passengers traveling both directions, which is used to determine the installed capacity required.

For the commuter bus running ethanol this equates to $3.25 \mathrm{kWh}$ per person and $6.5 \mathrm{MWh}$ for 1000 people in both directions.

\section{B. The Helicopter:}

We will now consider running the helicopter on hydrogen. Even though hydrogen is not a direct replacement for kerosene or aviation fuel in a turbine engine, it will be assumed that some solution to this problem exists. For this study however we will consider a fuel cell and electric motor to convert the energy and turn the rotor.

Generally hydrogen is produced by gas reforming, which requires natural gas to begin with. Hydrogen can also be extracted from water by electrolysis, however, this process requires a considerable amount of energy. For the purpose of this discussion only electrolysis will be considered as a plausible means of producing hydrogen.

Assuming the helicopter is powered by a fuel cell with $40 \%$ efficiency and the original turbo shaft engine had an efficiency of $70 \%$, the energy required to fly the helicopter at $120 \mathrm{~km} / \mathrm{h}$ would be $13.3 \mathrm{GJ}$, based on the initial energy requirement of $7.6 \mathrm{GJ}$.

Using an energy density of $120 \mathrm{MJ} / \mathrm{kg}$ for hydrogen, we calculate the mass of hydrogen required to be $111 \mathrm{~kg}$. About $9 \mathrm{~kg}$ of water and $55 \mathrm{kWh}$ of energy is required to produce $1 \mathrm{~kg}$ of hydrogen [7].

To produce sufficient hydrogen thus requires $999 \mathrm{~kg}$ of water and $6100 \mathrm{kWh}$ of electrical energy to fly a single $200 \mathrm{~km}$ trip. Calculations for flying at $240 \mathrm{~km} / \mathrm{h}$ are done similarly. This yields $765 \mathrm{~kg}$ water and $4675 \mathrm{kWh}$ of electrical energy. These results are tabulated in Table VII.

If an average sized helicopter can transport 6 passengers, the energy requirement results in $1.02 \mathrm{MWh}$ per person at $120 \mathrm{~km} / \mathrm{h}$, or $0.78 \mathrm{MWh}$ per person at $240 \mathrm{~km} / \mathrm{h}$. For 1000 passengers doing the round trip this would mean $2040 \mathrm{MWh}$ at $120 \mathrm{~km} / \mathrm{h}$ or $1560 \mathrm{MWh}$ at $240 \mathrm{~km} / \mathrm{h}$.

Table VII Resources required for producing hydrogen

\begin{tabular}{|c|cc|}
\hline Traveling speed $(\mathbf{k m} / \mathbf{h})$ & $\mathbf{1 2 0}$ & $\mathbf{2 4 0}$ \\
\hline Electrical energy & $6100 \mathrm{kWh}$ & $4675 \mathrm{kWh}$ \\
Water & $999 \mathrm{~kg}$ & $765 \mathrm{~kg}$ \\
Hydrogen mass produced & $111 \mathrm{~kg}$ & $85 \mathrm{~kg}$ \\
\hline
\end{tabular}

\section{The Superbus}

Calculations are first done for averaging $120 \mathrm{~km} / \mathrm{h}$. The mechanical power required to sustain this speed is determined by the aerodynamic properties of the Superbus as well as the rolling resistance of the tires. Electrical power required is slightly more due to efficiencies of the electric motor and inverter. 
Using the following different design parameters used for the Superbus:

- Air density: $\rho=1.293 \mathrm{~kg} / \mathrm{m}^{3}$

- Drag coefficient: $\mathrm{C}_{\mathrm{d}}=0.2$

- Rolling resistance coefficient: $\mathrm{C}_{\mathrm{rr}}=0.012$

- Frontal area: $\mathrm{A}=4.42 \mathrm{~m}^{2}$

- Air velocity: $\mathrm{v}=33.33 \mathrm{~m} / \mathrm{s}$

- Vehicle mass: $\mathrm{m}=8500 \mathrm{~kg}$

Mechanical power required can be calculated using (1). Factoring in the gearbox, motor and inverter efficiency gives the continuous electrical power required from the Superbus battery terminals at $120 \mathrm{~km} / \mathrm{h}$ to be $69 \mathrm{~kW}$.

Electrical energy required is $110.4 \mathrm{kWh}$. When traveling at $240 \mathrm{~km} / \mathrm{h}$ the power required to overcome drag and resistance increases to almost $280 \mathrm{~kW}$, but journey time is once again reduced to 50 minutes. Electrical energy required for traveling at $240 \mathrm{~km} / \mathrm{h}$ increases to $232.4 \mathrm{kWh}$.

The Superbus is designed to seat 25 occupants, so each person will require $4.5 \mathrm{kWh}$ at $120 \mathrm{~km} / \mathrm{h}$ and $9.3 \mathrm{kWh}$ at $240 \mathrm{~km} / \mathrm{h}$. For 1000 people completing a round trip, 9MWh would be required for $120 \mathrm{~km} / \mathrm{h}$ travel and $18.6 \mathrm{MWh}$ at $240 \mathrm{~km} / \mathrm{h}$.

\section{RESULTS}

Energy requirements for all discussed vehicles as well as capacity required from the electricity grid are summarized in Table VIII and IX. Electrical energy requirements per vehicle are normalized to energy requirement per person. Table VIII contains figures for vehicles traveling at $120 \mathrm{~km} / \mathrm{h}$ whereas in Table IX figures are for vehicles traveling at $240 \mathrm{~km} / \mathrm{h}$.

Of notable interest is the significantly large amount of energy required for the helicopter in comparison to the road going vehicles. Also of interest is the impact of using cellulose based ethanol compared to corn based ethanol. By using the process of cellulolysis to produce what is chemically identical to ethanol, the electrical demand is even lower than that of a battery electric vehicle.

The process of producing bio-ethanol is still in its infancy and there is still room for advances in development, as can clearly be seen from this study. It might be possible that the processes involved in producing ethanol are further improved in future, demanding even less energy from the grid. On the other hand, the electrical side of power generation and distribution is quite mature. Large electrical generators have very high efficiency and transmission of electrical power is also very efficient. This makes the possibility of the energy requirement for an electric vehicle like the Superbus decreasing unlikely.
Table VIII Energy consumption and power requirement traveling at $120 \mathrm{~km} / \mathrm{h}$

\begin{tabular}{|c|c|c|c|}
\hline \multicolumn{2}{|c|}{$\begin{array}{c}\text { Energy per } \\
\mathbf{1 0 0 0}\end{array}$} & $\begin{array}{c}\text { Installed } \\
\text { capacity }\end{array}$ & kWh/person \\
\hline Cohicle at 120km/h & $23,4 \mathrm{MWh}$ & $1 \mathrm{MW}$ & 403 \\
Commuter bus (com ethanol) & $6,5 \mathrm{MWh}$ & $0,3 \mathrm{MW}$ & 112 \\
Helicopter (Hydrogen) & $2040 \mathrm{MWh}$ & $85 \mathrm{MW}$ & 340,000 \\
Superbus (Electric) & $9 \mathrm{MWh}$ & $2,3 \mathrm{MW}$ & 360 \\
\hline
\end{tabular}

Table IX Energy consumption and power requirement traveling at $240 \mathrm{~km} / \mathrm{h}$

\begin{tabular}{|c|c|c|c|}
\hline \multicolumn{2}{|c|}{$\begin{array}{c}\text { Energy per } \\
\mathbf{1 0 0 0}\end{array}$} & $\begin{array}{c}\text { Installed } \\
\text { Capacity }\end{array}$ & kWh/person \\
\hline Commuter bus (corn ethanol) & $\mathrm{N} / \mathrm{A}$ & $\mathrm{N} / \mathrm{A}$ & $\mathrm{N} / \mathrm{A}$ \\
Commuter bus (cellulose ethanol) & $\mathrm{N} / \mathrm{A}$ & $\mathrm{N} / \mathrm{A}$ & $\mathrm{N} / \mathrm{A}$ \\
Helicopter (Hydrogen) & $1560 \mathrm{MWh}$ & $65 \mathrm{MW}$ & 260,000 \\
Superbus (Electric) & $18.6 \mathrm{MWh}$ & $0,8 \mathrm{MW}$ & 744 \\
\hline
\end{tabular}

Although it is assumed that in the future cellulolysis will be used commercially, yield rates and efficiencies might vary from what is predicted. For time being, the technology exists, but it is not available for use in mass production of bio ethanol.

The figures in Tables VIII and IX indicate the amount of energy that will be required in addition to what is generated today. This additional energy can be supplied in a variety of ways, but for sustainable energy the options are generally less.

This does not necessarily mean that there are few options, for there are a large amount of sustainable energy sources currently under investigation.

Some of these energy sources include:

- Hydro power

- Wind power

- Solar power

- Wave power (Archimedes wave swing)

Some possible methods of generating this power requirement for sustainable transport are given in Tables $\mathrm{X}$ and XI. The figures given in Table $\mathrm{X}$ are for generating $1 \mathrm{MW}$ of peak power, which is adequate for powering the commuter bus at $120 \mathrm{~km} / \mathrm{h}$ or the Superbus traveling at $240 \mathrm{~km} / \mathrm{h}$.

Powering the helicopter at $240 \mathrm{~km} / \mathrm{h}$ presents another scenario, where the power requirement is 65 times larger. These figures are presented in Table XI, clearly illustrating the difference. 
Table X Possible methods of generating $1 \mathrm{MW}$

\begin{tabular}{|c|c|c|}
\hline Source & Power output & Amount required \\
\hline Siemens SWT-1.3-62 Wind Turbine & $250 \mathrm{~kW}$ & 4 \\
Solar panels & $300 \mathrm{~W}$ & $6.700 \mathrm{~m}^{2}$ \\
Hydroelectric station & $2 \mathrm{GW}$ & 0.0005 \\
Archimedes wave swing [10] & $187 \mathrm{~kW}$ & 5.4 \\
\hline
\end{tabular}

Table XI Possible methods of generating $65 \mathrm{MW}$ for powering hydrogen helicopter

\begin{tabular}{|c|c|c|}
\hline Source & Power output & Amount required \\
\hline Siemens SWT-1.3-62 Wind Turbine & $250 \mathrm{~kW}$ & 260 \\
Solar panel & $300 \mathrm{~W}$ & $22.000 \mathrm{~m}^{2}$ \\
Hydroelectric station & $2 \mathrm{GW}$ & 0.0325 \\
Archimedes wave swing [10] & $187 \mathrm{~kW}$ & 347.6 \\
\hline
\end{tabular}

Power requirements are calculated based on demand of transport for a 24 hour day. The required surface area covered by solar panels is calculated assuming a panel power output of $300 \mathrm{~W} / \mathrm{m}^{2}$ and based on light being available for 12 hours a day. For the Archimedes wave swing the power output is based on $1.64 \mathrm{GWh}$ of energy available per annum. Wind turbines and hydroelectric generators are assumed to be generating 24 hours a day.

\section{CONCLUSION}

The electrical demand from the electricity grid for future fuels independent of fossil fuels has been calculated. This has been done by considering a $200 \mathrm{~km}$ route and transporting 1000 passengers per day on a round trip using different vehicles. Energy requirements for each vehicle have been calculated as well as energy required for transporting a significant number of passengers. From this the peak demand from the grid has been estimated.

Using cellulolysis to break down cellulose for the production of ethanol significantly increases the yield of fuel produced and dramatically decreases the electrical energy required to produce it. The decrease is in fact, so significant that the total energy contribution from the utility grid is less than that required for the Superbus.

By reviewing these results, it seems that the Superbus is not necessarily the best option regarding total energy requirement from the electricity grid. The reality is that in the medium to long term the Superbus will be operational, where technology required for production of cellulose based ethanol is still being researched.

Furthermore, the commercial bus does not have any high speed capabilities. The Superbus might therefore not have the lowest energy requirement in the future, but for now it does and it succeeds in making traveling at high speeds for point to point transportation economical and fast.

\section{REFERENCES}

[1] International Energy Agency, "Key world energy statistics 2006", IEA Publications, p24, 2006

[2] International Energy Agency, "Renewables in global energy supply, An IEA fact sheet", IEA Publications, January 2007

[3] Manufacturers datasheet, "Mercedes Benz OM904LA commercial diesel engine", datasheet as on August 2004, from www.mercedesbenz.nl

[4] Manufacturers datasheet, "Bell 407 commercial helicopter", engine datasheet as on January 2006, from www.bellhelicopter.com

[5] Chevron products company, "Aviation Fuels Technical Review (FTR-3)", sourced from website, February 2007, http:/www.chevron.com/products/prodserv/fuels/bulletin/aviationfuel/

[6] M.L. Wald, "Is Ethanol for the Long Haul?", Scientific American, January 2007

[7] U. Bossel, "Does a hydrogen economy make sense?", Proceedings of the IEEE, vol 94, no 10, October 2006

[8] U. Bossel, "Well-to-Wheel Studies, Heating Values and the Energy Conservation Principle", European Fuel Cell Forum, 29 October 2003

[9] Optare Solo Datasheet, www.optare.com

[10] H. Polinder, B.C. Mecrow, A.G. Jack, P. Dickinson, M.A. Mueller, "Linear generators for direct-drive wave energy conversion", Electric Machines and Drives Conference, IEMDC'03, IEEE International, Volume 2, 1-4 June 2003 Page(s):798 - 804 vol.2

[11] Natural Resources Defence Council and Climate Solutions, "Ethanol, Energy Well Spent", Survey of studies published since 1990, February 2006 